\title{
SPIDER DIVERSITY (ARACHNIDA; ARANEAE) IN DIFFERENT PLANTATIONS OF WESTERN GHATS, WAYANAD REGION, INDIA
}

\author{
Fathima P Shabnam ${ }^{1}$, Smija M Kunnath ${ }^{1 *}$, Sruthi Rajeevan ${ }^{1}$, Puthanpurayil K Prasadan ${ }^{1}$, \\ AMBALAPARAMBIL V SUDHIKUMAR ${ }^{2}$ \\ ${ }^{1}$ Department of Zoology, Kannur University, Mananthavady Campus, Wayanad- 670 645, Kerala, \\ India.E-mails:fathimashabnamp22@gmail.com,smijamkkunnath@gmail.com,sruthiraj0496@, \\ gmail.com,pkprasadan@gmail.com \\ ${ }^{2}$ Centre for Animal Taxonomy and Ecology, Department of Zoology, Christ College (Autonomous), \\ Irinjalakuda - 680 125, Kerala, India.E-mail: avsudhi@rediffmail.com
}

*Corresponding author: smijamkkunnath@gmail.com (Smija M Kunnath)

\begin{abstract}
.
The study was conducted to explore the spider diversity in different plantations of Western Ghats Wayanad, Kerala State, India. The investigation was carried out for a one year period from February 2019 to February 2020. A total of 93 species belonging to 71 genera under 19 families were recorded from the selected habitats. This represents $49 \%$ families recorded from the Western Ghats, Kerala. The highest species richness was found in the coffee plantation (site A) with 51 species belonging to 11 families. The tea plantation (site B) recorded 26 species belonging to 11 families. The rubber plantation (site C) showed the lowest species richness with 16 species belonging to ten families. Guild structure analysis of the collected spiders revealed seven functional groups viz.., orb-web builders, stalkers, ambushers, cob-web builders, ground runners, foliage runners and sheet-web builders. It is concluded that the structure of the vegetation is expected to influence the diversity of spiders in different plantations.
\end{abstract}

Key words: agro-ecosystem, ecological guilds, ground dweller, orb web weaver, plant dweller, species richness, stalker, web builder

\section{INTRODUCTION}

Spiders are diverse and ubiquitous invertebrate predators in terrestrial ecosystems (Wise 1993; Nyffeler 2000; Lone et al. 2015; Radermacher et al. 2020). Spiders are considered the major agent controlling insect communities in agricultural ecosystems because of their high abundance and insectivorous foraging habit (Nyffeler and Benz 1987; Marc et al. 1999; Nyffeler 2000; Ludwig et al. 2018). Studies have shown that the exclusive predatory behaviour of spiders has a notable impact on the agro ecosystems (Samiayyan 2014; Michalko et al. 2019) and influence of spiders on prey populations depend on spider density or biomass (Greenstone 1999; Riechert 1999; Sunderland and Samu 2000; Liu et al. 2015).

Habitat heterogeneity has been suggested to be an important component that affects the density and diversity of spider species in both natural (Greenstone 1984) and agro ecosystems (Rypstra and Carter 1995; Downie et al. 1999). The habitat heterogeneity is represented mainly by vegetational diversity, architectural features, level of vegetational stratification, water availability and topsoil structure. The structural complexity of habitats offers the spa- tial arrangement for web placement; therefore, web building spiders are particularly more responsive to structural complexity (Colebourne 1974; Riechert and Gillespie 1986; Uetz 1991).

In agro-ecosystems, a diverse group of spiders may inhabit a wide range of biotopes and they are likely to be active throughout the day. Therefore, assemblages of spider species will leave fewer refuges for potential prey in time and space. Spiders usually exert a strong influence on pest numbers in concert with other natural enemies. By reason of variation in spider size and/or prey capture strategies, spiders are able to capture prey that varies in size and/or developmental stages (Sunderland 1999; Henaut et al. 2001). In addition to killing the pests by direct attack, spiders cause pest mortality by dislodging them from plants or trapping them in the webs. On the whole, spiders promote the diversity and stability of the natural enemy community and they act as a robust basis of pest control (Sunderland 1999).

Western Ghats mountain ranges of India, by far the most densely populated global biodiversity hotspot (Cinacotta et al. 2000), has a mosaic of natural, semi-natural and agro-ecosystems in close 
proximity to one another. Human-induced changes in land use are globally ubiquitous and specifically of high importance in the Western Ghats (Rahman et al. 2011). With an increase in anthropogenically dominated habitats, previously abundant natural habitats have become smaller and more fragmented (Kumara et al. 2004; Chakraborty et al. 2019). The replacement of native forests by monoculture plantations affects the diversity of biological communities, particularly in montane forest ecosystems of southern Western Ghats (Anand et al. 2010). On the whole, agricultural land-use changes have affected the forest ecosystems of Wayanad in two major ways: first, a conspicuous shrinkage of the forest cover and the second, the loss of structural integrity of the remaining forests (De Fries et al. 2010; Kumar et al. 2010). Due to enculturation, unregulated mass tourism, deforestation and monoculture agricultural practices - the habitats in Wayanad are degraded and biodiversity is vanishing at a faster rate. Previous studies in this ecosystem have focused on vertebrates (Ranganathan et al. 2010; Caudill et al. 2014), while only a few studies have been performed on the relationship between spiders and plantations (Kapoor 2008; Sruthi et al. 2019, Prasad et al. 2020). The present study aimed at estimating species richness and composition of spiders in different plantations of the Western Ghats, Wayanad region, Kerala.

\section{Materials ANd Methods}

\section{Study Area}

Wayanad district is one of the hill stations of Kerala set high on the Western Ghats with an altitude ranging from 700 to 2100 meters. Wayanad falls under two climatic zones: per humid and moist sub-humid zones (Raju et al. 2013) (Fig. 1). Annual rainfall averages $1635 \mathrm{~mm}$ with the highest rainfall recorded in the regions of Lakkidi, Vythiri and Meppadi in Wayanad. Forests in the Wayanad District are unique and exclusive in composition and they represent the transition zone of moist laden forests of South-Western Ghats to the Northern drier forests. Total forest area of Wayanad is $2,131 \mathrm{~km}^{2}$ which represents $83.3 \%$ of the total geographical area of the District (Balasubramanian et al. 2019). High altitude agriculture of Wayanad is characterized by the specialized multi-tier cropping system. The gross cropped area of Wayanad covers $97.82 \%$ of the geographical area and is dominated by cash crops. The major plantation crops include the perennial crops such as coffee, tea, pepper, rubber and cardamom that together represent

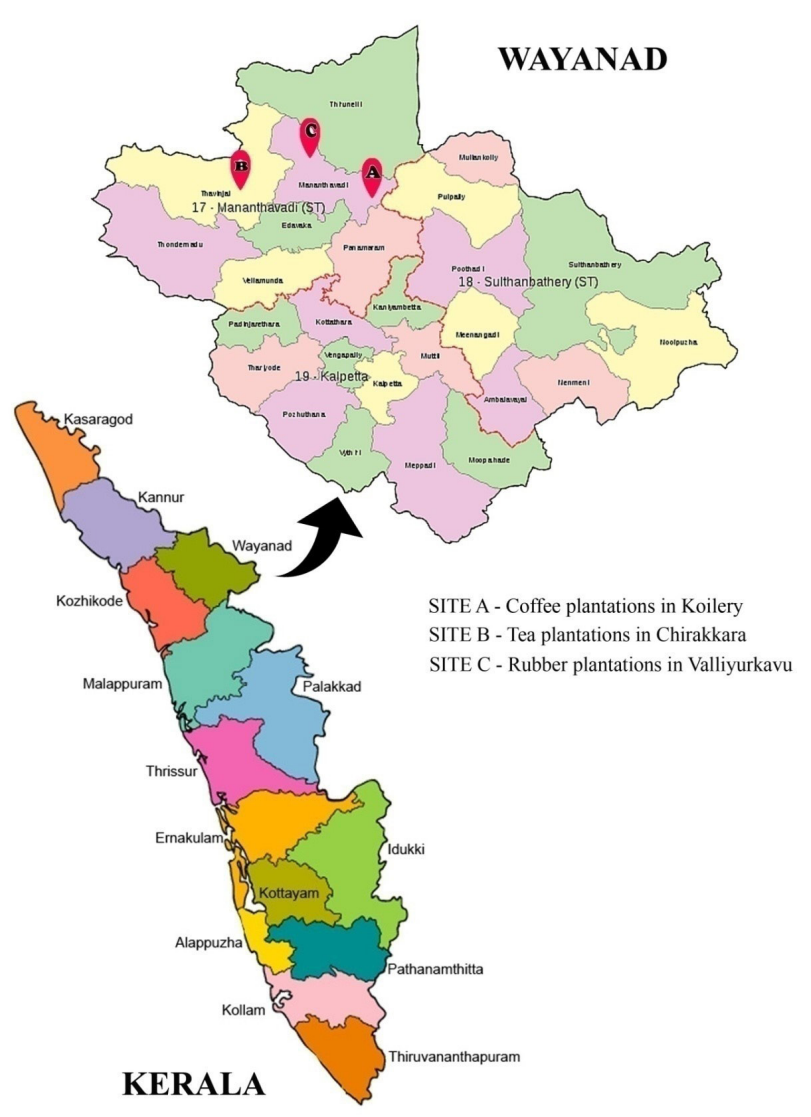

Figure 1: Study location.

$38 \%$ of the total cropped area (Kumar and Ichikawa 2010).

Three stations were chosen for the present study (Fig. 2).

1. SITE A - Coffee plantations in Koilery

Koilery $(11.7867268,76.0455579)$ is a small village located about $7.9 \mathrm{~km}$ away from Mananthavady, and is rich in agricultural fields and plantations. Robusta is the most popular variety of coffee being cultivated here. The site constitutes wide range of other plants and animals.

2. SITE B - Tea plantations in Chirakkara Chirakkara $(11.8535994,75.9644254)$ is a village located $11 \mathrm{~km}$ away from Mananthavady. The area is rich with tea plantations. The region encompassed ditches and streams.

3. SITE C - Rubber plantations in Valliyurkavu Valliyurkavu $(11.804787,76.027880)$ is a small village located about $3.8 \mathrm{~km}$ away from Mananthavady. The area is rich with different plantations.

\section{Methodology}

The current investigation was carried out from February 2019 to February 2020. Spiders were col- 


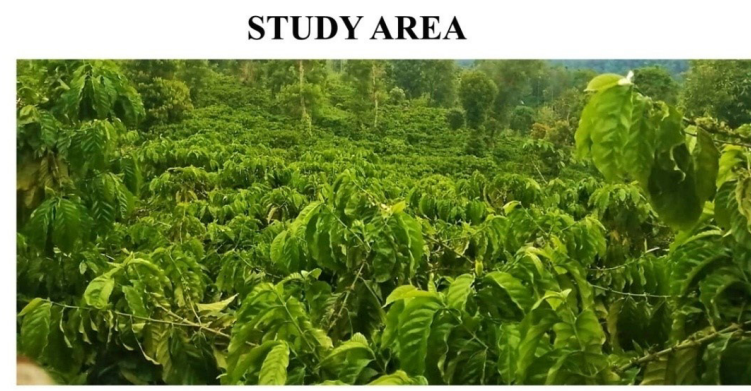

Coffee plantations in Koilery (SITE A)

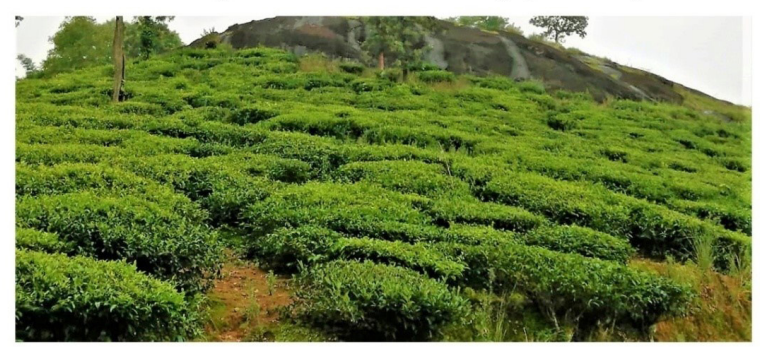

Tea plantations in Chirakkara (SITE B)

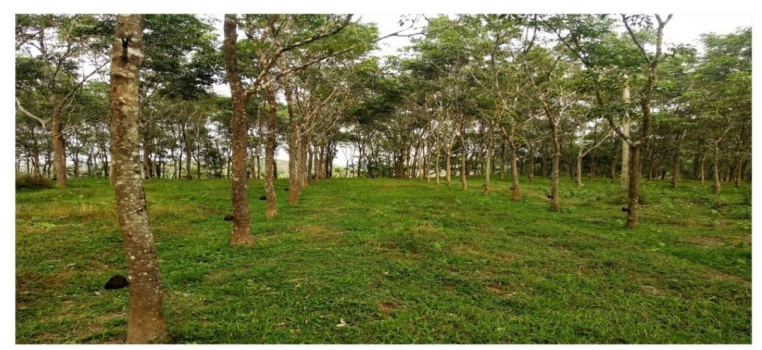

Rubber plantations in Valliyurkavu (SITE C)

Figure 2: Study sites.

lected by Line transect and Quadrat methods. At each site, two transects were established (transect lines were $500 \mathrm{~m}$ wide) in a 0.405 hectare study area. Two $10 \mathrm{mx} 10 \mathrm{~m}$ quadrates were placed at every $200 \mathrm{~m}$ interval. All surveys were conducted in the morning hours between 7:00 am to 11:30 am.Visual searching method was followed for sampling. Ground search was made under leaf litter and fallen or dry wood. Sweep netting method was followed to collect the foliage dwelling spiders in the herbs and shrubs. Beating was done with a wooden stick and an inverted umbrella was placed under the trees to catch the spiders. Data on web patterns and microhabitat types were recorded with every encounter. The microhabitats types such as ground, litter, foliage, flower, and tree trunk were recorded visually for the presence of spiders. The collected spiders were placed separately in vials with $70 \%$ ethyl alcohol. The collection date, compartment name and nature of habitat were recorded on each vial. Spiders were photographed using Oppo A71 13-mega pixel camera and identified up to the species level following the identification keys (Gravely 1931; Helsdingen 1969; Tikader and
Malhotra 1980; Tikader and Biswas 1981; Tikader 1982; Żabka 1985; Barrion and Litsinger 1995; Huber 2000; Caleb 2016; Sankaran and Sebastian 2018). The spider guild classification was composed according to the families of spiders collected (Sebastian et al. 2012).

\section{RESULTS}

A total of 93 species belonging to 71 genera under 19 families were recorded from the selected habitats. In the present study, Araneidae was the dominant family constituting 23 species under 13 genera, followed by Salticidae (20 species), Thomisidae (9 species), Theridiidae ( 8 species), Tetragnathidae $(7$ species), Lycosidae (5 species), Oxyopidae (3 species), Sparassidae (3 species), Uloboridae (3 species), Pholcidae ( 2 species), Corinnidae ( 2 species), Clubionidae (1 species), Cheiracanthiidae (1 species), Hersiliidae (1 species), Linyphiidae (1 species), Liocranidae (1 species), Scytodidae (1 species), Selenopidae (1 species) and Philodromidae (1 species) (Table 1, Fig. 3).

The results reveal that the coffee plantation has the highest diversity of spiders when compared to the other habitats. The highest species richness was recorded in the coffee plantation (site A) with 51 species belonging to 11 families. Of these, 53\% were web builders, $37 \%$ represented plant dwellers and $10 \%$ represented ground dwellers. The tea plantation (site B) exhibited the second highest species richness with 26 species belonging to 11 families. Of these, $46 \%$ web builders, $46 \%$ represented plant dwellers, and only $8 \%$ living in ground. The rubber plantation (site C) showed the lowest species richness with 16 species belonging to ten families. Of these, plant

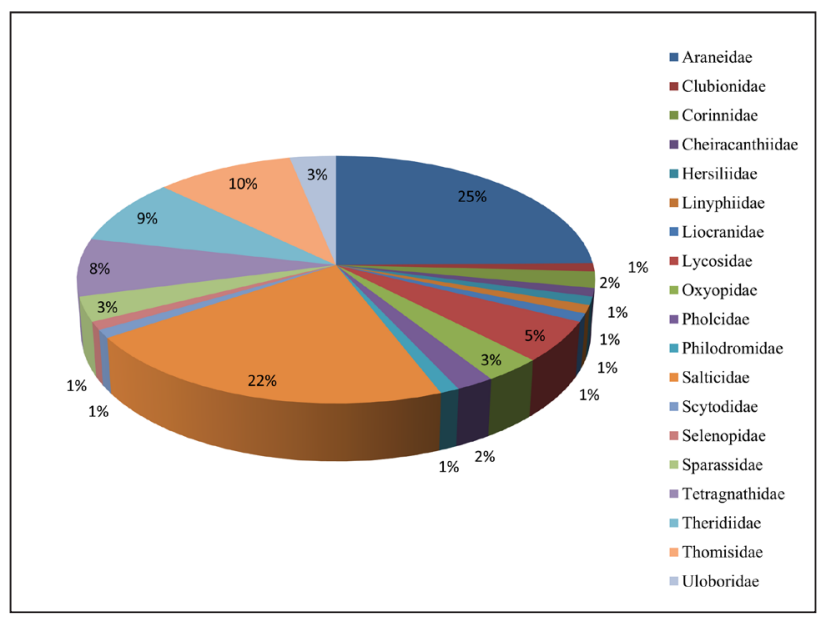

Figure 3: Species distribution in different families found in the study area. 
Fathima P Shabnam et al. - Spider Diversity in Different Plantations of Western Ghats, India

Table 1: Systematic list of spiders recorded from different plantations of Western Ghats, Wayanad

\begin{tabular}{|c|c|c|c|}
\hline $\begin{array}{l}\text { SL } \\
\text { NO. }\end{array}$ & SPECIES & $\begin{array}{l}\text { SL } \\
\text { NO. }\end{array}$ & SPECIES \\
\hline \multicolumn{2}{|r|}{ Araneidae (Orb-web builders) } & 35 & Pardosa sumatrana (Thorell, 1890) \\
\hline 1 & Acusilas coccineus Simon, 1895 & \multicolumn{2}{|r|}{ Oxyopidae (Stalkers) } \\
\hline 2 & Arachnura angura Tikader, 1970 & 36 & Hamadruas sp. \\
\hline 3 & Araneus ellipticus (Tikader \& Bal, 1981) & 37 & Oxyopes javanus Thorell, 1887 \\
\hline 4 & Araneus mitificus (Simon, 1886) & 38 & Oxyopes shweta Tikader, 1970 \\
\hline 5 & Araneus sp. & \multicolumn{2}{|r|}{ Pholcidae (Cob web builder) } \\
\hline 6 & Argiope pulchella Thorell, 1881 & 39 & Pholcus sp. \\
\hline 7 & Argiope sp. & 40 & Smeringopus pallidus (Blackwall, 1858) \\
\hline 8 & Cyclosa hexatuberculata Tikader, 1982 & \multicolumn{2}{|r|}{ Philodromidae (Ambushers) } \\
\hline 9 & Cyclosa sp. & 41 & Tibellus elongatus Tikader, 1960 \\
\hline 10 & Cyrtarachne sp. & \multicolumn{2}{|r|}{ Salticidae (Stalkers) } \\
\hline 11 & Cyrtophora cicatrosa (Stoliczka, 1869) & 42 & $\begin{array}{l}\text { Asemonea tenuipes (O. Pickard-Cambridge, } \\
1869 \text { ) }\end{array}$ \\
\hline 12 & Cyrtophora citricola (Forsskal, 1775) & 43 & Brettus cingulatus Thorell, 1895 \\
\hline 13 & Eriovixia laglaizei (Simon, 1877) & 44 & Burmattus sp. \\
\hline 14 & Eriovixia sp. & 45 & Chalcotropis pennata Simon, 1902 \\
\hline 15 & Gasteracantha geminata (Fabricius, 1798) & 46 & Epeus tener (Simon, 1877 ) \\
\hline 16 & Gasteracantha kuhli C. L. Koch, 1837 & 47 & Epeus indicus Prószyński, 1992 \\
\hline 17 & Herennia multipuncta (Doleschall, 1859) & 48 & Epocilla aurantiaca (Simon, 1885) \\
\hline 18 & Neoscona bengalensis Tikader\& Bal, 1981 & 49 & Hasarius adansoni (Audouin, 1826) \\
\hline 19 & Neoscona mukerjei Tikader, 1980 & 50 & Hyllus semicupreus (Simon, 1885) \\
\hline 20 & Neoscona sp. & 51 & Menemerus bivittatus (Dufour, 1831) \\
\hline 21 & Neoscona theisi (Walckenaer, 1841) & & \\
\hline 22 & Nephila pilipes (Fabricius, 1793) & 52 & (O. Pickard-Cambridge, 1869) \\
\hline 23 & Paraplectana sp. & 53 & Myrmarachne sp. \\
\hline \multicolumn{2}{|r|}{ Clubionidae (Foliage runners) } & 54 & Phintella vittata (C. L. Koch, 1846) \\
\hline 24 & Clubiona sp.1 & 55 & Plexippus paykulli (Audouin, 1826) \\
\hline \multicolumn{2}{|r|}{ Corinnidae (Ground runners) } & 56 & Plexippus petersi (Karsch, 1878) \\
\hline 25 & Apochinomma nitidum(Thorell, 1895) & 57 & Portia fimbriata (Doleschall, 1859) \\
\hline 26 & Castianeira zetes Simon, 1897 & 58 & Rhene flavigera (C. L. Koch, 1846) \\
\hline \multicolumn{2}{|r|}{ Cheiracanthiidae (Foliage runners) } & 61 & Siler semiglaucus (Simon, 1901) \\
\hline 27 & Cheiracanthium melanostomum (Thorell, & 59 & Telamonia dimidiata (Simon, 1899) \\
\hline \multirow{2}{*}{\multicolumn{2}{|c|}{ Hersiliidae (Foliage runners) }} & 60 & Thiania bhamoensis Thorell, 1887 \\
\hline & & \multicolumn{2}{|r|}{ Scytodidae (Ground-runners) } \\
\hline 28 & Hersilia savignyi Lucas, 1836 & 62 & Scytodes thoracica (Latreille, 1802) \\
\hline \multicolumn{2}{|r|}{ Linyphiidae (Sheet-web builder) } & \multicolumn{2}{|r|}{ Selenopidae (Ambushers) } \\
\hline 29 & Neriene sundaica (Simon, 1905) & 63 & Selenops sp. \\
\hline \multicolumn{2}{|r|}{ Liocranidae (Ground runner) } & \multicolumn{2}{|r|}{ Sparassidae (Ambushers) } \\
\hline 30 & Oedignatha sp. & 64 & Heteropoda venatoria (Linnaeus, 1767) \\
\hline \multicolumn{2}{|r|}{ Lycosidae (Ground runners) } & 65 & Martensopoda sp. \\
\hline 31 & Hippasa agelenoides (Simon, 1884) & 66 & Olios sp. \\
\hline 32 & Lycosa tista Tikader, 1970 & \multicolumn{2}{|r|}{ Tetragnathidae (Orb-web builder) } \\
\hline 33 & $\begin{array}{l}\text { Pardosa mysorensis (Tikader \& Mukerji, } \\
\text { 1971) }\end{array}$ & 67 & Leucauge decorata (Blackwall, 1864) \\
\hline \multirow{2}{*}{34} & \multirow{2}{*}{$\begin{array}{l}\text { Pardosa pseudoannulata (Bösenberg \& } \\
\text { Strand, 1906) }\end{array}$} & 68 & Leucauge tessellata (Thorell, 1887) \\
\hline & & 69 & Opadometa fastigata (Simon, 1877) \\
\hline
\end{tabular}


Fathima P Shabnam et Al. - Spider Diversity in Different Plantations of Western Ghats, India

Table 1, continued: Systematic list of spiders recorded from different plantations of Western Ghats, Wayanad

\begin{tabular}{|l|l|}
\hline $\begin{array}{c}\text { SL } \\
\text { NO. }\end{array}$ & \multicolumn{1}{|c|}{ SPECIES } \\
\hline 70 & Tetragnatha hasselti Thorell, 1890 \\
\hline 71 & Tetragnatha mandibulata Walckenaer, 1841 \\
\hline 72 & Tetragnatha viridorufa Gravely, 1921 \\
\hline 73 & Tylorida ventralis (Thorell, 1877) \\
\hline \multicolumn{2}{|c|}{ Theridiidae (Cob web builder) } \\
\hline 74 & Achaearanea durgae Tikader 1970 \\
\hline 75 & $\begin{array}{l}\text { Argyrodes flavescens } \text { O. Pickard-Cambridge, } \\
\text { 1880 }\end{array}$ \\
\hline 76 & Argyrodes sp. \\
\hline 77 & Chikunia nigra (O. Pickard-Cambridge,1880) \\
\hline 78 & Chrysso urbasae (Tikader, 1970) \\
\hline 79 & Episinus sp. \\
\hline 80 & Meotipa sp. \\
\hline 81 & $\begin{array}{l}\text { Twaitesia margaritifera } \text { O. Pickard-Cam- } \\
\text { bridge, } 1881\end{array}$ \\
\hline
\end{tabular}

\begin{tabular}{|l|l|}
\hline $\begin{array}{r}\text { SL } \\
\text { NO. }\end{array}$ & \multicolumn{1}{|c|}{ ThECIES } \\
\hline \multicolumn{2}{|c|}{ Thomisidae (Ambushers) } \\
\hline 82 & $\begin{array}{l}\text { Amyciaea forticeps (O. Pickard-Cambridge, } \\
1873)\end{array}$ \\
\hline 83 & Boliscus sp. \\
\hline 84 & Diaea sp. \\
\hline 85 & Indoxysticus minutus (Tikader, 1960) \\
\hline 86 & Loxobates sp. \\
\hline 87 & Phrynarachne sp. \\
\hline 88 & Strigoplus netravati Tikader, 1963 \\
\hline 89 & Thomisus lobosus Tikader, 1965 \\
\hline 90 & Thomisus shillongensis Sen, 1963 \\
\hline \multicolumn{2}{|c|}{ Uloboridae (Orb-web builders) } \\
\hline 91 & Uloborus khasiensis Tikader, 1969 \\
\hline 92 & Uloborus krishnae Tikader, 1970 \\
\hline 93 & Zosis geniculata (Olivier, 1789) \\
\hline
\end{tabular}

dwellers represented $56 \%$ while web builders and ground dwellers comprised 31 and $13 \%$, respectively.

The dominant spider family found in the coffee plantation was Araneidae (31\%) followed by Salticidae $(23 \%)$ and Thomisidae $(12 \%)$. Liocranidae $(2 \%)$, Oxyopidae (2\%) and Linyphiidae (2\%) were the least observed families in the coffee plantation. In the tea plantation, Araneidae (23\%) was the most abundant family, followed by Salticidae (15\%), Thomisidae (11\%) and Sparassidae (11\%). Scytodidae (4\%),

Selenopidae (4\%), Oxyopidae (4\%), and Lycosidae $(4 \%)$ were the least observed families in the tea plantation. The dominant spider family recorded in the rubber plantation was Salticidae $(25 \%)$ followed by Lycosidae (13\%), Tetragnathidae (13\%), Theridiidae $(13 \%)$. Araneidae $(6 \%)$, Oxyopidae (6\%), Hersiliidae $(6 \%)$, Cheiracanthiidae (6\%), Clubionidae $(6 \%)$ and Philodromidae $(6 \%)$ were rarely noted families in the rubber plantation (Figs. 4).

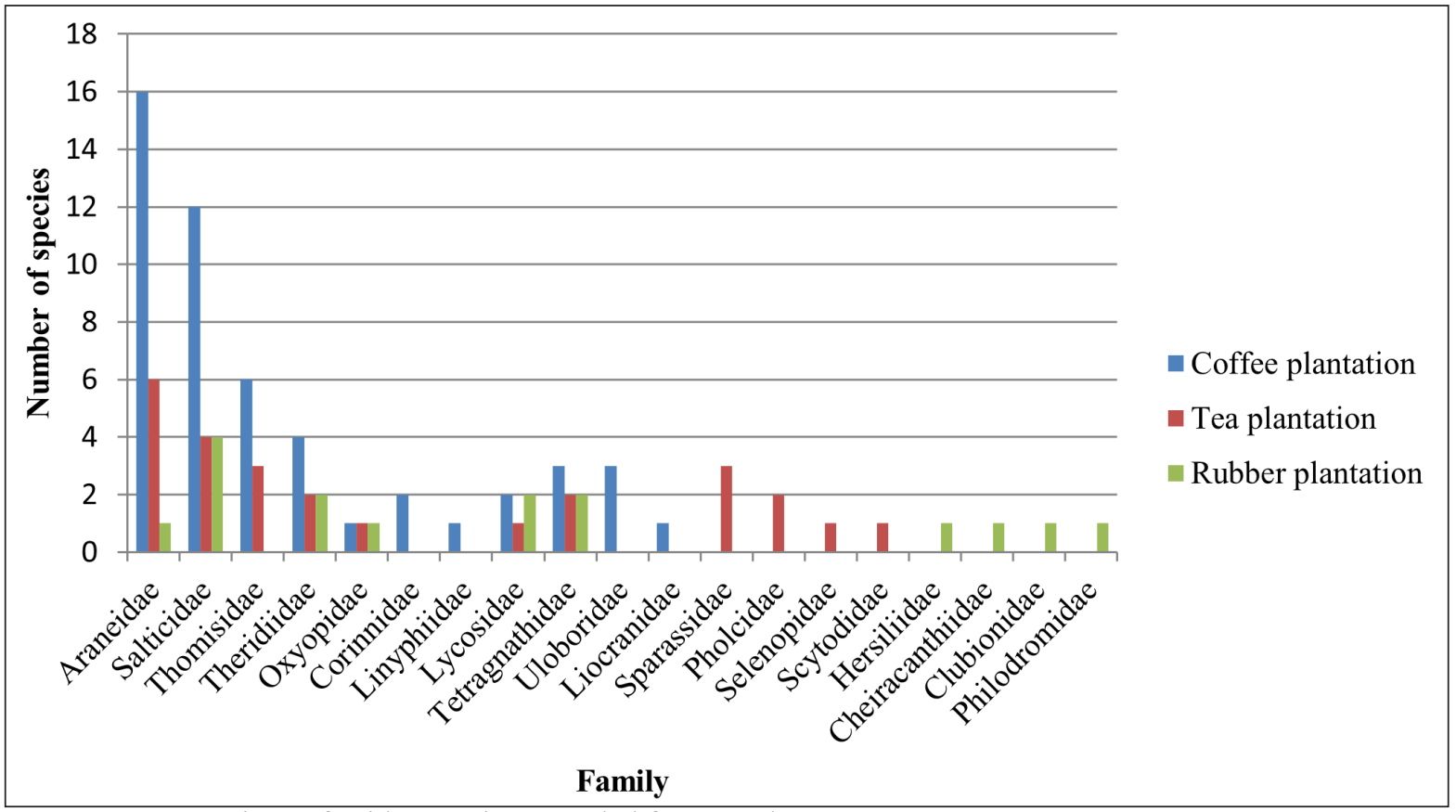

Figure 4: Comparison of spider species recorded from Study areas. 


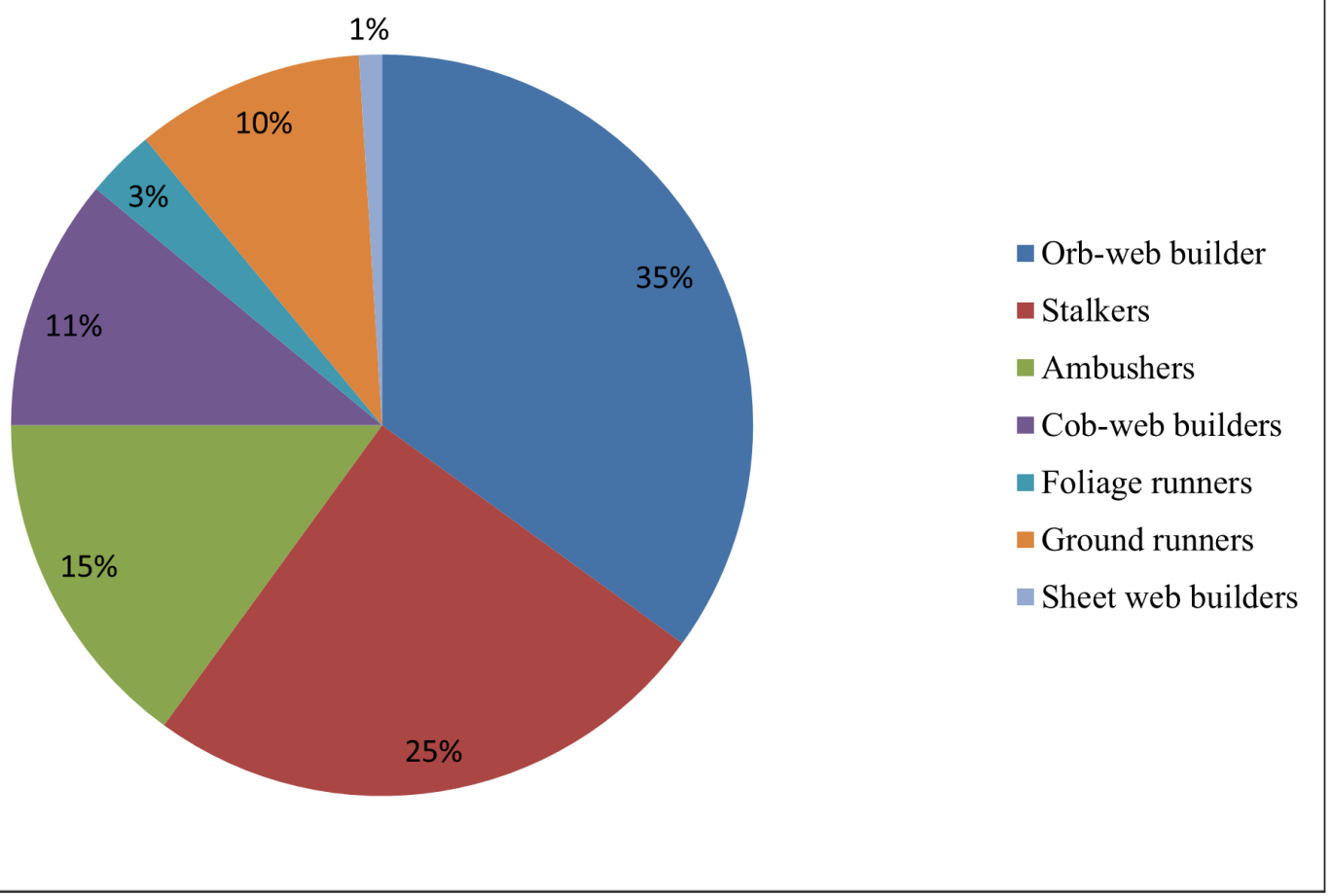

Figure 5: Guild structure analysis of spiders recorded from the study area

The spiders were grouped into seven functional guilds based on their foraging mode. Orb-web builders were the dominant feeding guilds with $35 \%$ followed by stalkers $25 \%$, ambushers $15 \%$, cob-web builders $11 \%$, ground runners $10 \%$, foliage runners $3 \%$ and sheet-web builders $1 \%$. The dominant orbweb builders constituted 33 species. Stalkers composed of a total of 23 species belonging to the families, Salticidae and Oxyopidae (Figs. 5-6).

\section{Discussion}

As generalists, spiders are ingenious predators and an integral part of ecosystem, playing an important role in the structure of food webs and communities (Bucher et al. 2015; Stokmane and Spungis 2016; Ludwig et al. 2018). Spiders have also an important role in the ecosystem maintenance and are considered as the prospective biological control agents (Riechert and Bishop 1990). The status of spider diversity is an important constraint to evaluate the community level of biological organization. Higher species diversity is an indication of a healthier and complex community because a greater variety of species allows more interactions, hence greater system stability which in turn indicates good environmental conditions (Hill 1973).

In the current study, a total of 93 species belonging to 71 genera under 19 families were recorded from the different plantations of the Western Ghats, Wayanad region, Kerala. The 19 families recorded from habitats of Western Ghats represent $49 \%$ of all currently recognised families from the Western Ghats, Kerala (Sebastian et al. 2012). Previous study by Sudhikumar et al. (2005) reported 72 species belonging to 57 genera of 20 families from Mannavan Shola forest, Munnar. Dey et al. (2013) recorded 47 spider species belonging to 36 genera of 14 families from the artificial mixed plantation in West Tripura, India. Jose et al. (2018) analysed the diversity of spiders in Kavvayi river basin and recorded 112 species belonging to 81 genera and 21 families. Sruthi et al. (2019) documented 150 species belonging to 73 genera under 20 families from different ecosystems of the Western Ghats, Wayanad. The number of families recorded in the present study is as high or higher than the numbers recorded for other habitats in the Western Ghats (Dey et al. 2013; Jose et al. 2018; Sruthi et al. 2019). The families that were abundant (such as Araneidae, Salticidae and Thomisidae) were also widely distributed in the different plantations of the Western Ghats, Wayanad region (Dharmaraj et al. 2017; Jose et al. 2018). The spiders of the families such as Liocranidae and Philodromidae were not as cosmopolitan in nature (Karthikeyani et al. 2017; Dhali et al. 2017) and they were recorded during the endeavour of the present study. 


\section{ARANEIDAE}
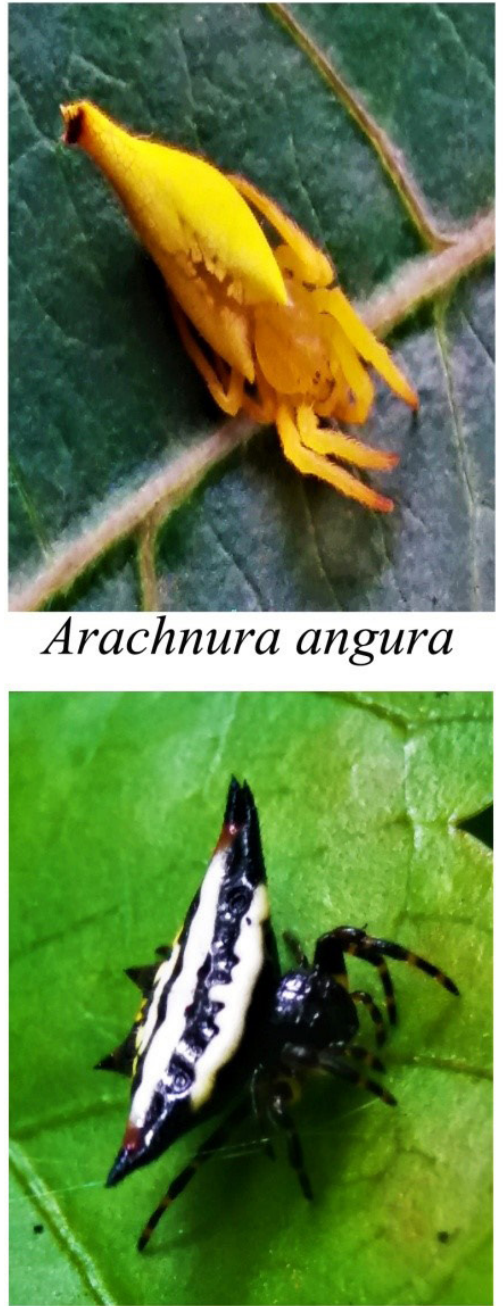

Gasteracantha geminata

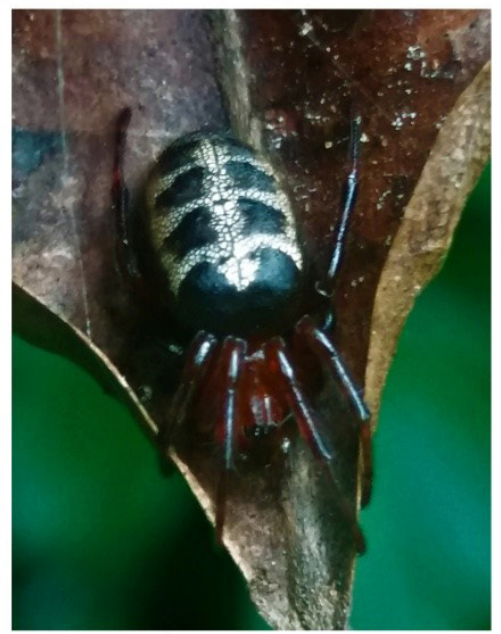

Acusilas coccineus

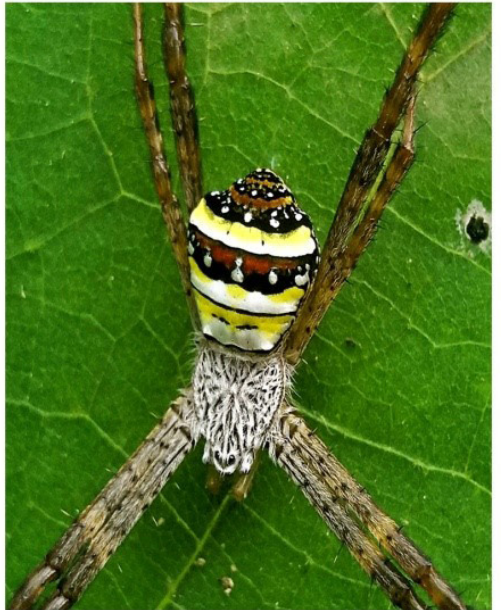

Argiope pulchella

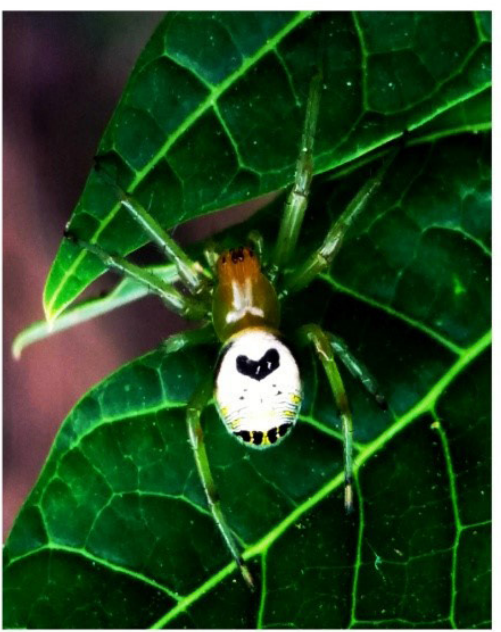

Araneus mitificus

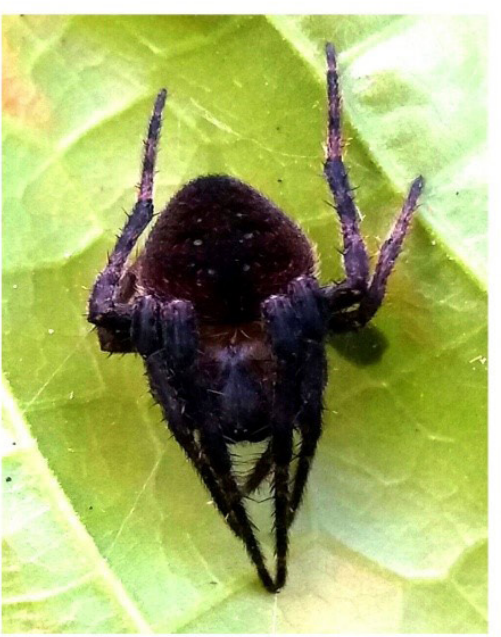

Neoscona sp.

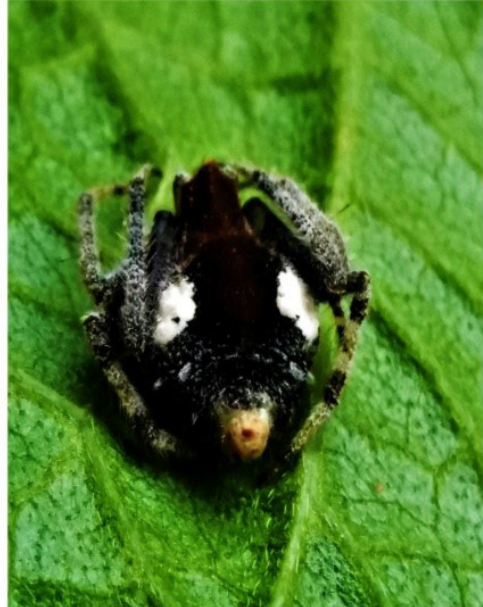

Eriovixia $s p$.

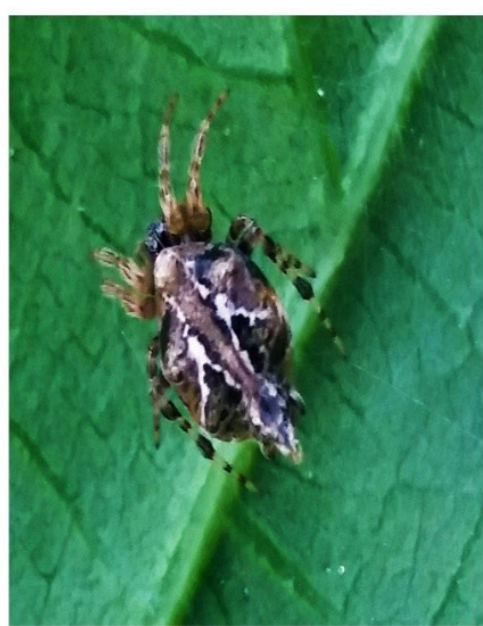

Cyclosa sp.

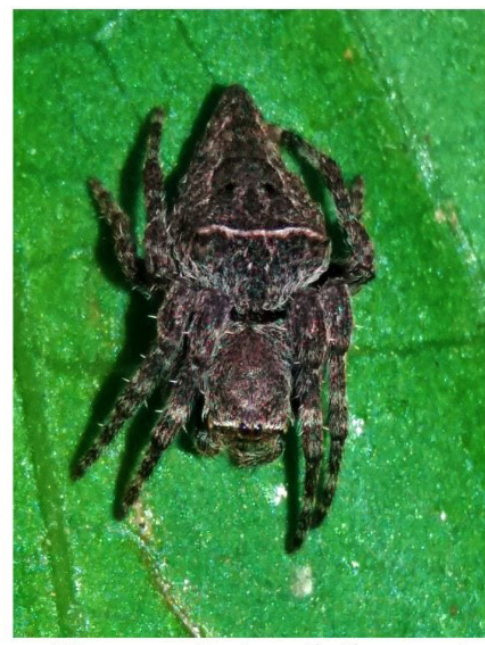

Parawixia dehaani

Figure 6: Spider species diversity in different families reported from different plantations of Western Ghats, Wayanad 


\section{SALTICIDAE}
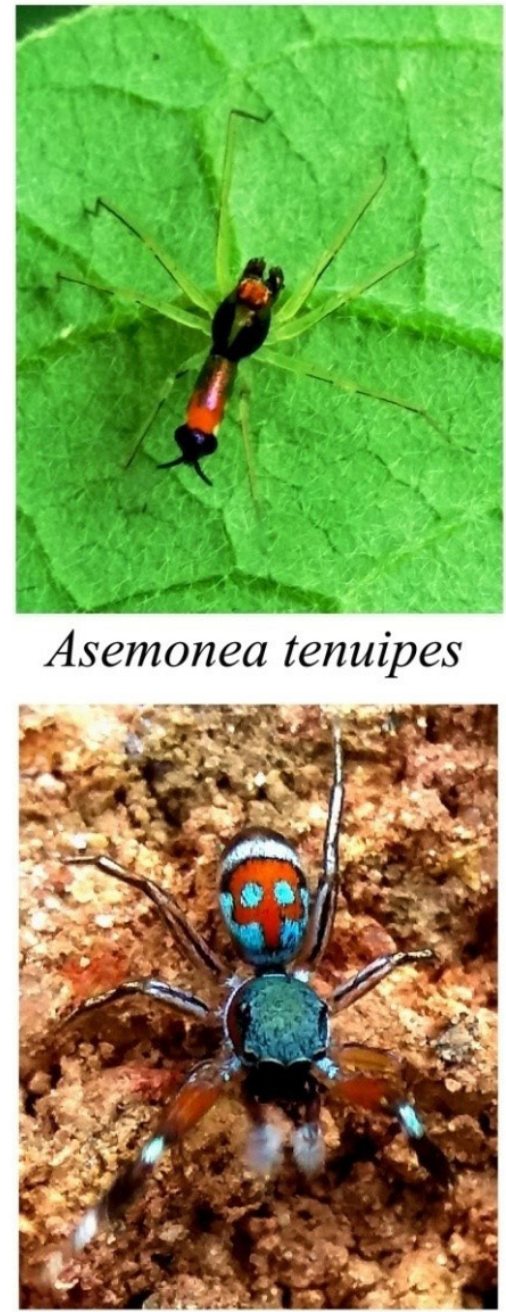

Siler semiglaucus

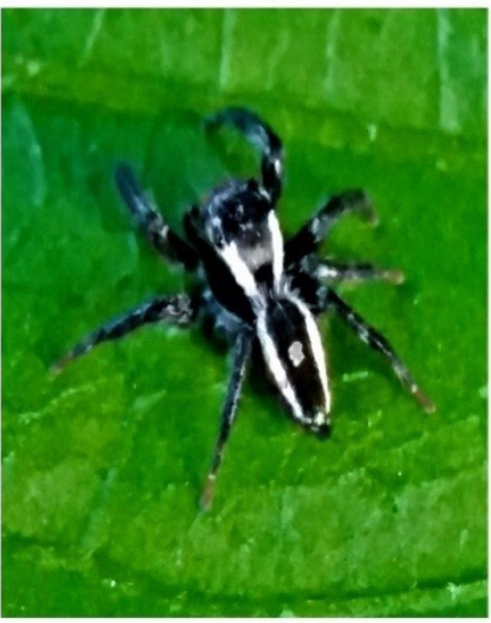

Carrhotus viduus

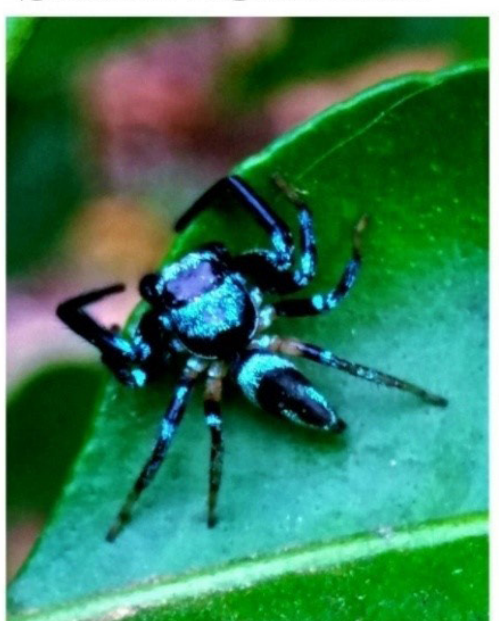

Thiania bhamoensis

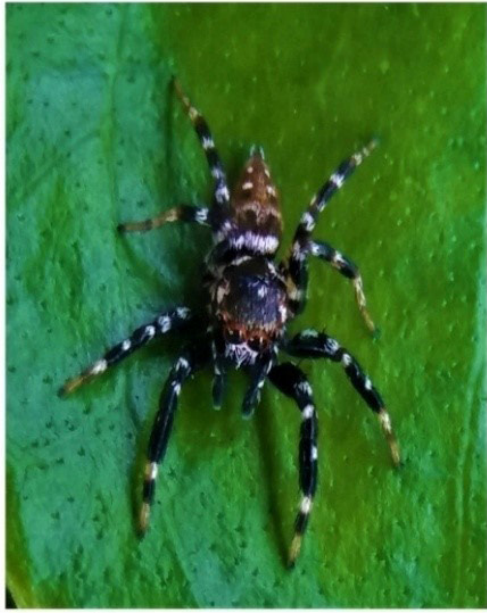

Burmattus sp.

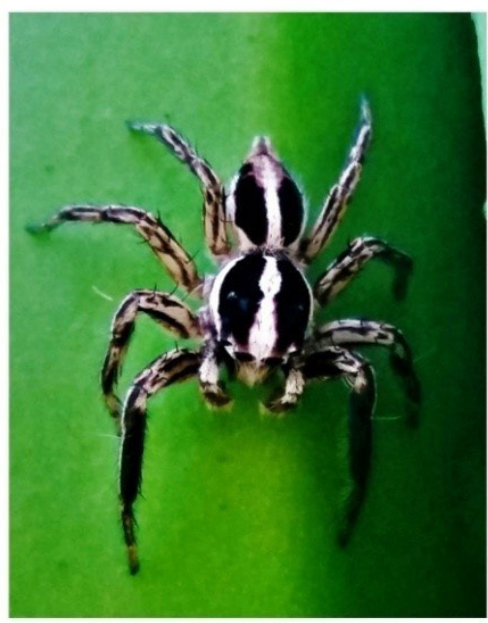

Plexippus paykulli

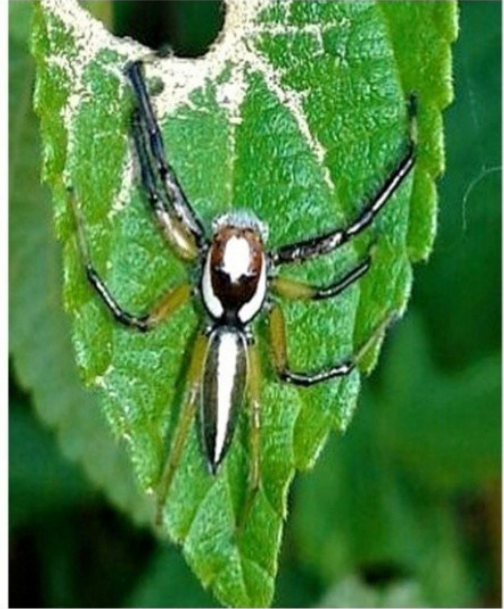

Telamonia dimidiata

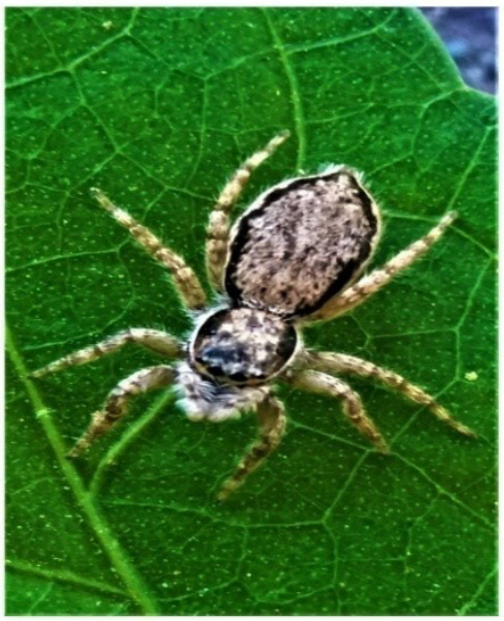

Menemerus bivittatus

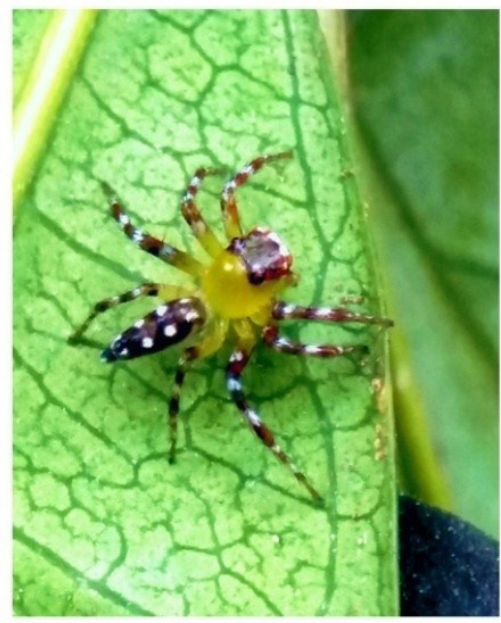

Epeus indicus

Figure 6: Spider species diversity in different families reported from different plantations of Western Ghats, Wayanad 


\section{TETRAGNATHIDAE}
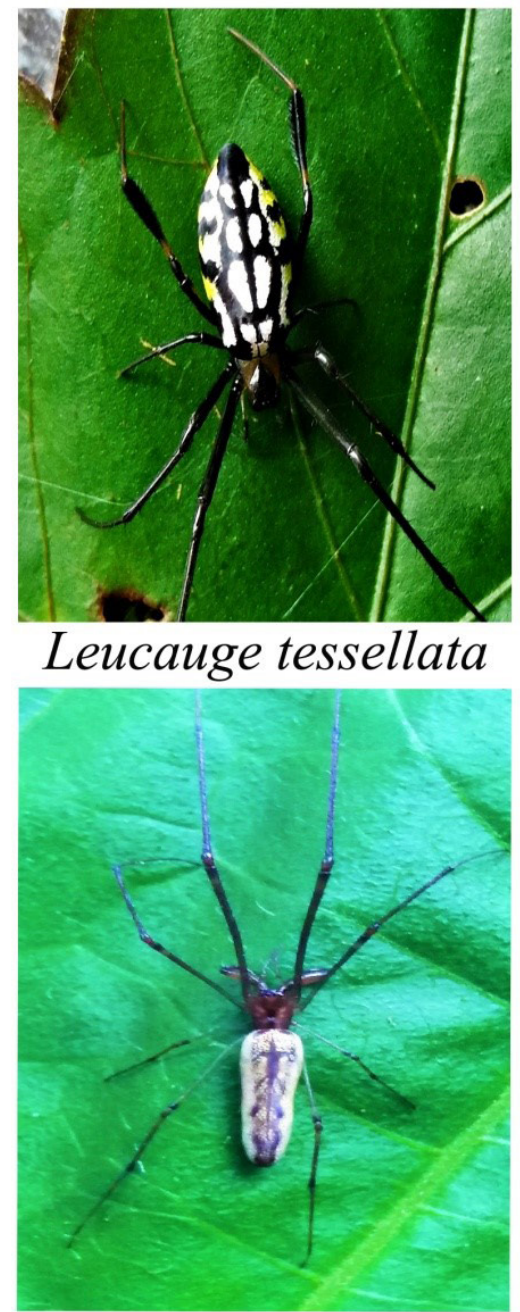

Tetragnatha mandibulata

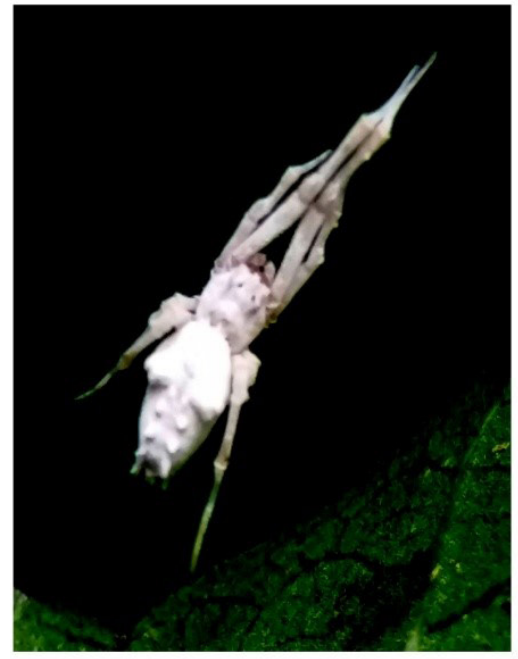

Uloborus krishnae
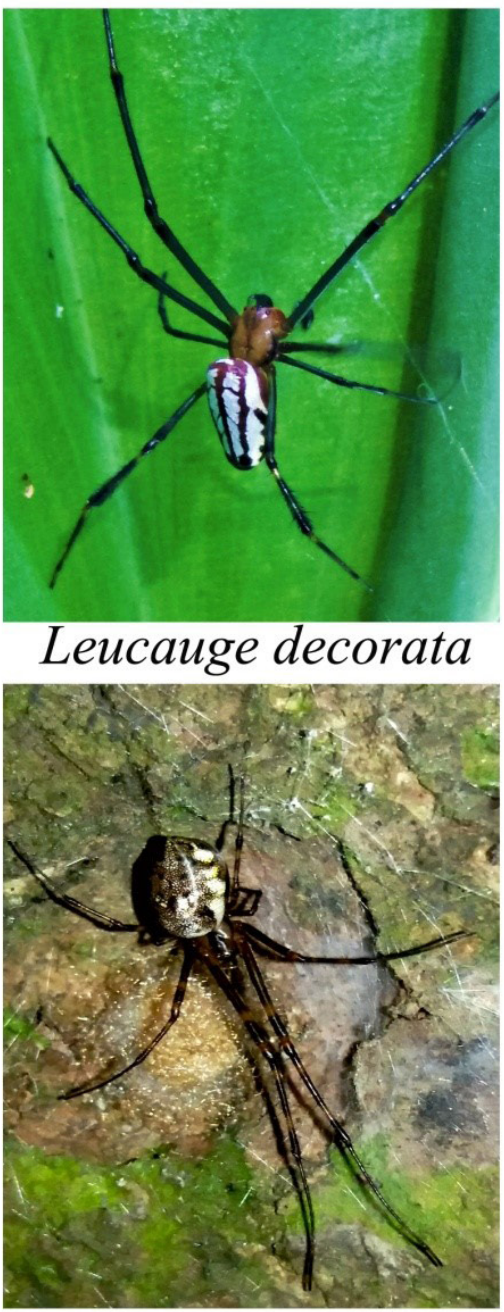

Tylorida ventralis Tetragnatha viridorufa ULOBORIDAE

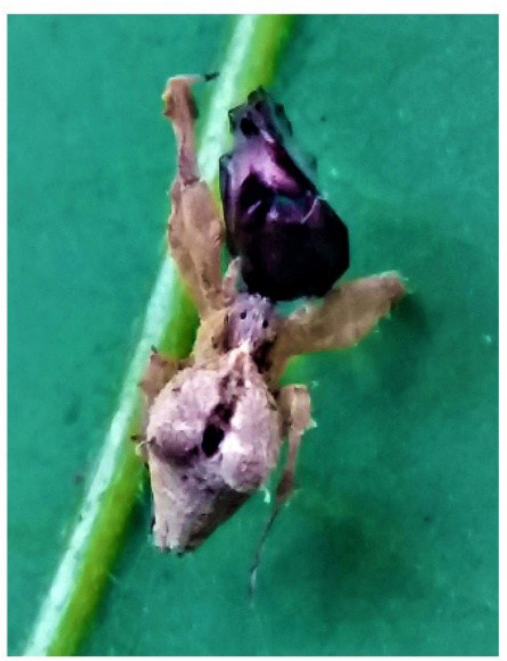

Uloborus khasiensis

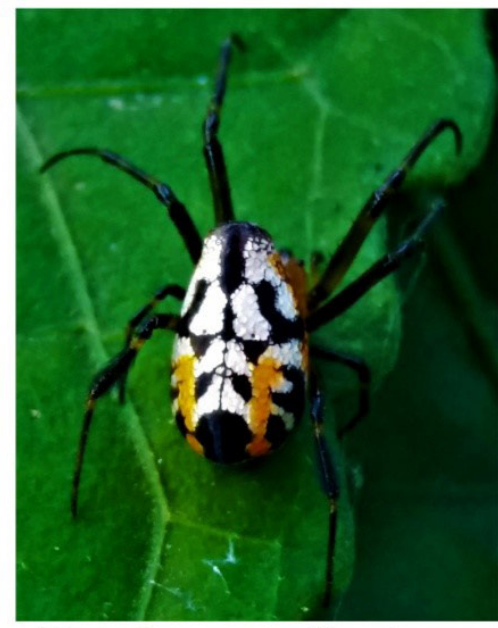

Opadometa fastigata
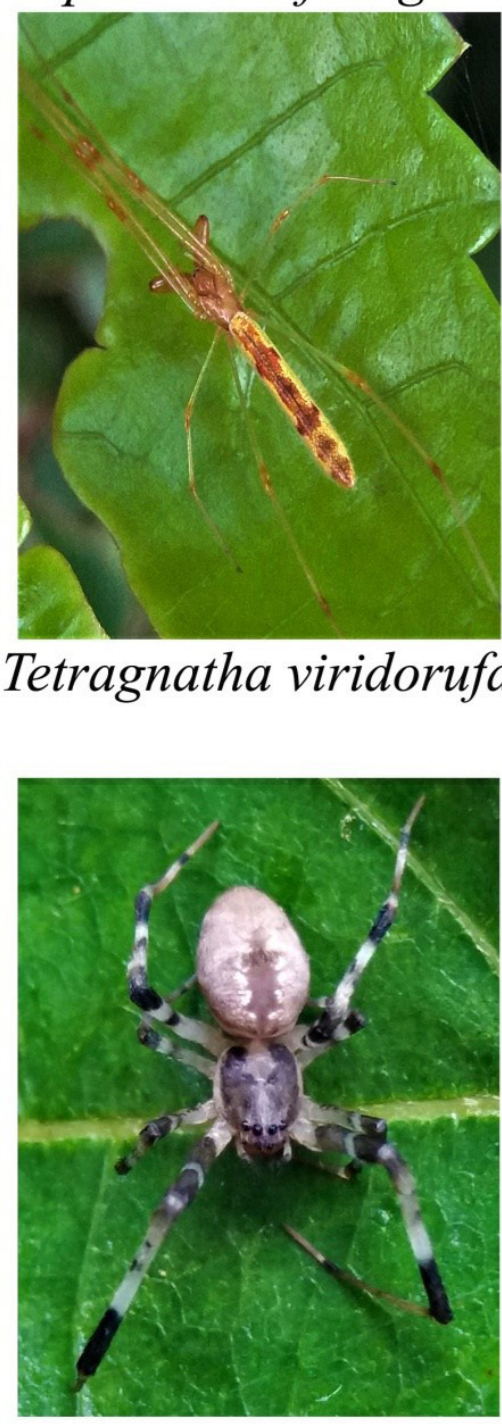

Zosis geniculata

Figure 6: Spider species diversity in different families reported from different plantations of Western Ghats, Wayanad 


\section{OXYOPIDAE}

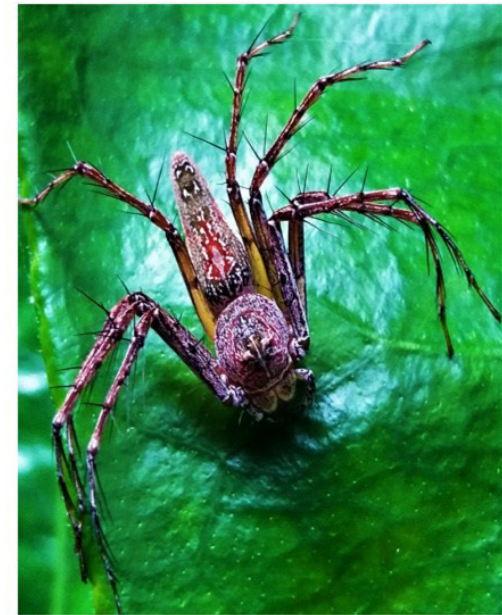

Hamadruas sp.

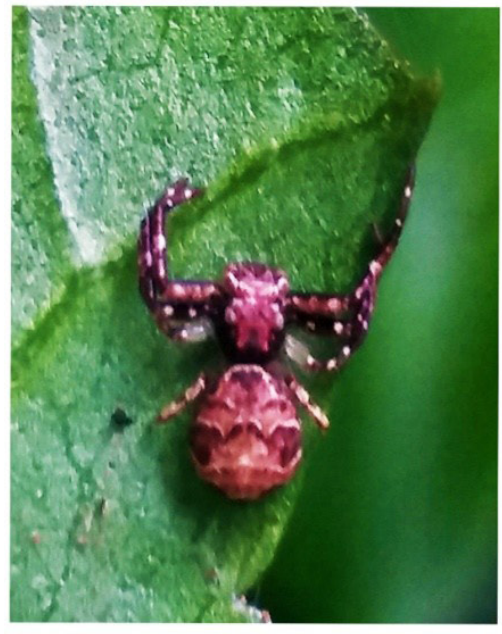

Strigoplus netravati

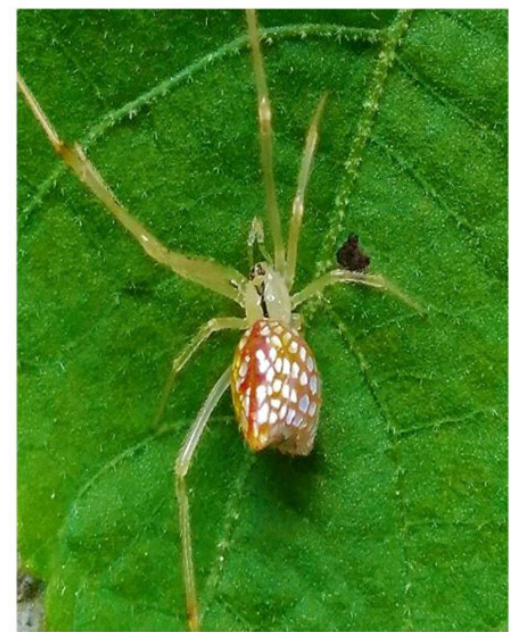

Twaitesia margaritifera

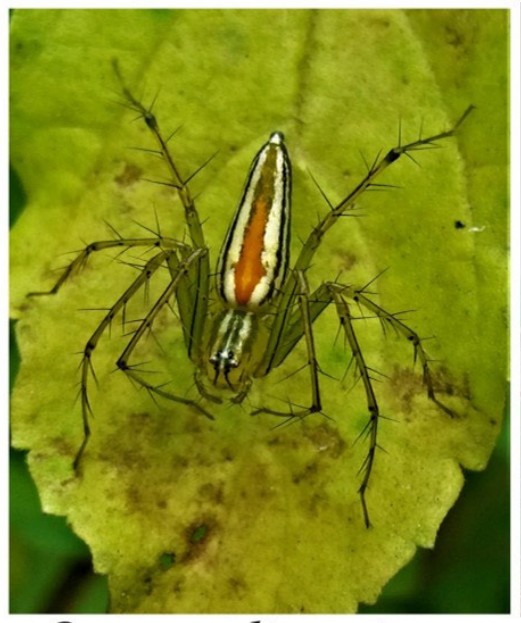

Oxyopes lineatipes. THOMISIDAE

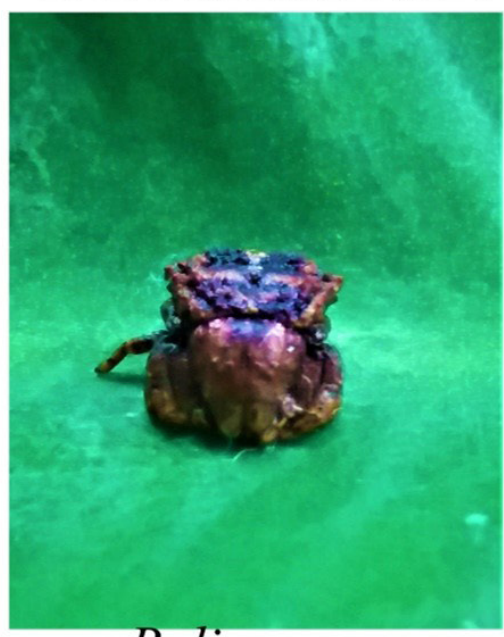

Boliscus sp. THERIDIIDAE

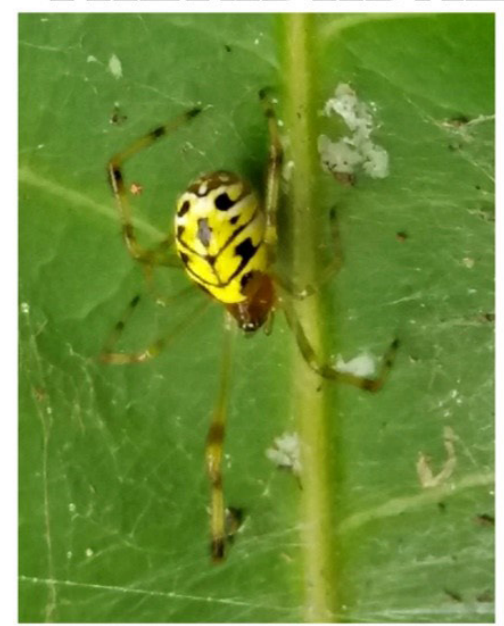

Chrysso urbasae

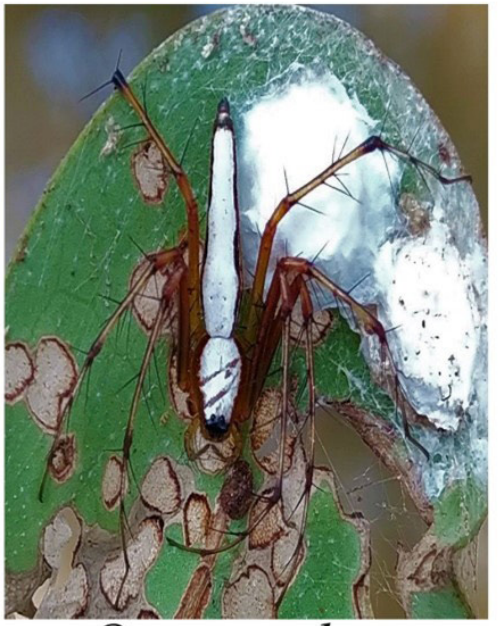

Oxyopes shweta

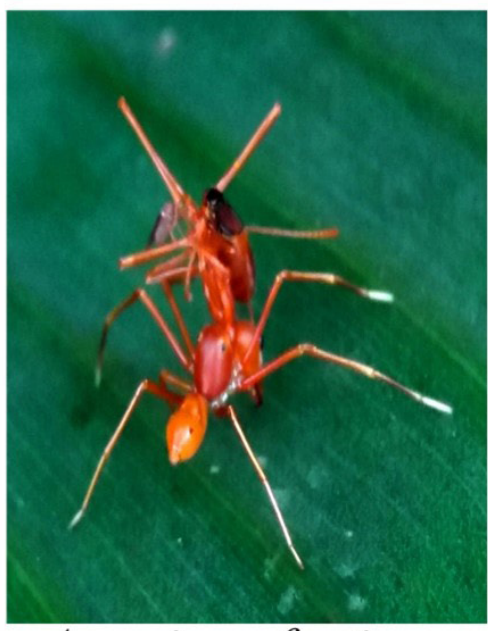

Amyciaea forticeps

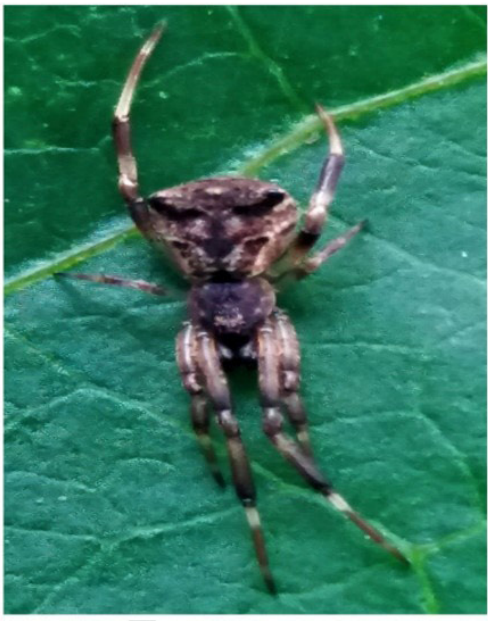

Episinus sp.

Figure 6: Spider species diversity in different families reported from different plantations of Western Ghats, Wayanad 


\section{SPARASSIDAE}

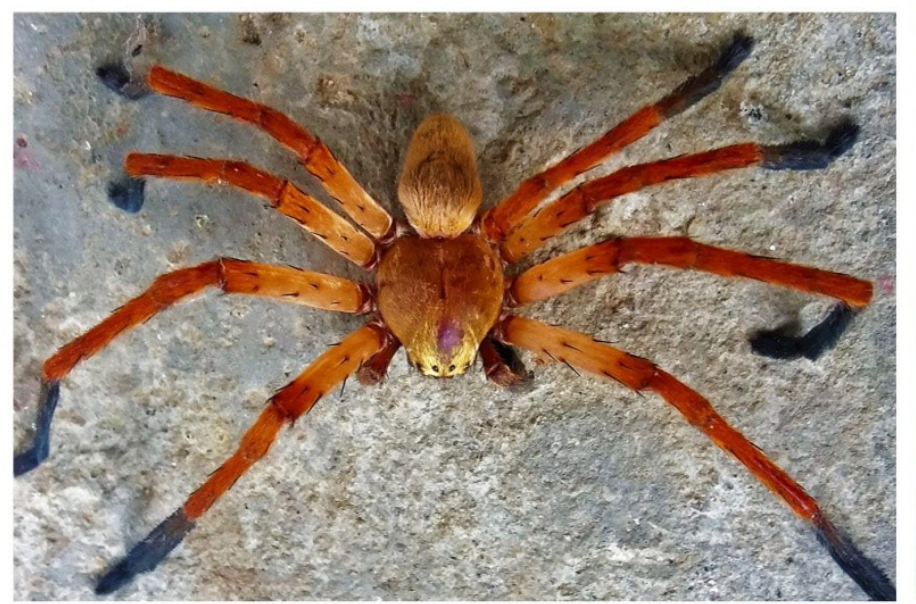

Olios sp.

\section{PHILODROMIDAE HERSILIIDAE}

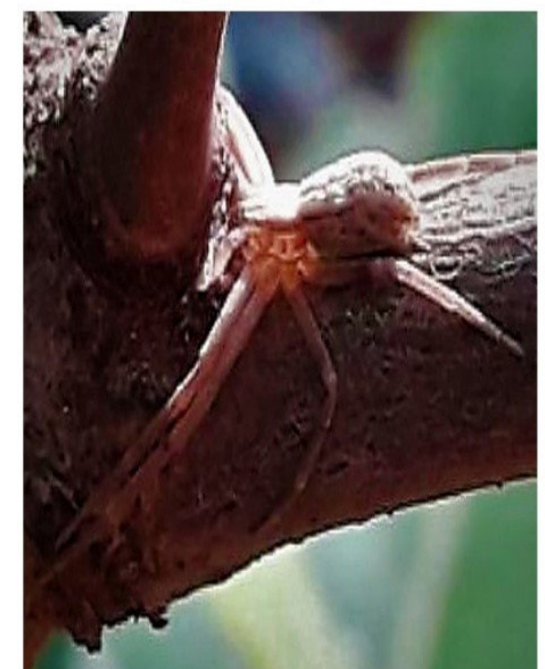

Tibellus elongatus

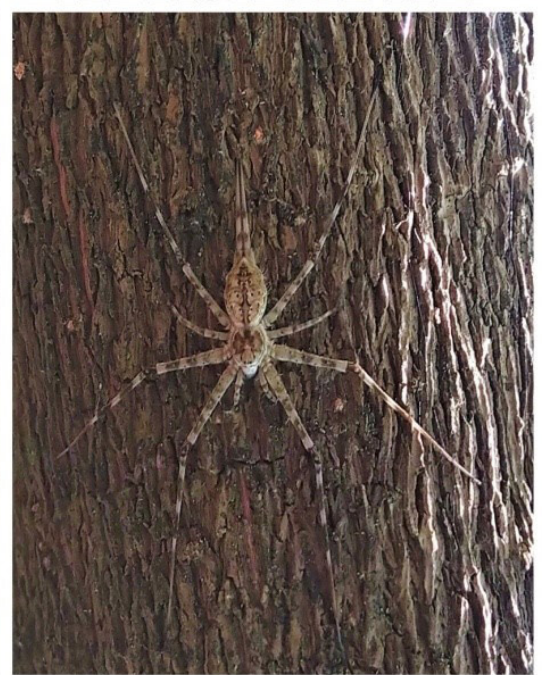

Hersilia savignyi

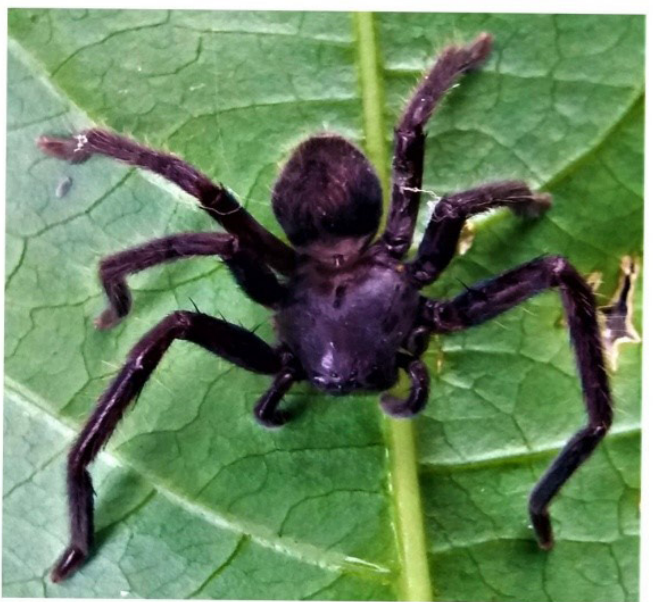

Martensopoda sp.

Figure 6: Spider species diversity in different families reported from different plantations of Western Ghats, Wayanad

The results of the present study indicate that the coffee plantations (site A) showed the highest species richness with 51 species belonging to 11 families. The vegetation structure of the habitat supports both the web building and non-web building spiders. Additionally, the exclusive presence of more spider species at one site may be related to the existence of a favourable microclimate and/or an adequate web support for these species. Besides, the site was less exposed to the application of chemical pesticides. When spiders were divided according to their functional group, there was a considerable effect of habitat on the richness of web builders and plant wanderers. The web building and plant wandering spiders depend on vegetation for some part of their lives, either for finding food or for web building (Sanders and Platner 2007). There were many more plant wanderers and web builders sampled than ground-dwellers. Hence, the structure of the vegetation is expected to influence the diversity of spiders found in the coffee plantation. Many other studies have also demonstrated that there exists a definite correlation between structural complexity of habitat and spider species diversity (Uetz 1979; Rosenzweig 1995; Rendon et al. 2006; Rodriguez et al. 2015; Malvido et al. 2020). In the current study, both the tea and rubber plantations exhibited lower species richness. These plantations comprise lower floral and faunal richness when compared to that of coffee plantation. In addition to this, exogenous applications of chemical pesticides 
could also influence the spider diversity of these regions. The lower species richness and abundance in the tea and rubber plantation systems could be due to lack of habitat heterogeneity. Land use intensification can reduce the abundance and diversity of spider species through physical removal, destruction of their microhabitats or through changing the microclimatic conditions within the habitat. Previous studies in the Western Ghats have also indicated the effects of land use changes on the diversity of soil biota (Rossi and Blanchart 2005; Rahman et al. 2011; Mandle and Ticktin 2015).

\section{ACKNOWLEDGEMENTS}

The authors acknowledge Officer-in-Charge, Western Ghats Field Research Centre, Zoological Survey of India, Calicut, Kerala, India for providing necessary facilities. We acknowledge the support of Sudhin P P, Centre for Animal Taxonomy and Ecology, Department of Zoology, Christ College (Autonomous), Irinjalakuda.

\section{REFERENCES}

Anand, M. O., Krishnaswamy, J., Kumar, A., Bali, A. (2010) Sustaining biodiversity conservation in human-modified landscapes in the Western Ghats: remnant forests matter. Biological Conservation, 143, 2363-2374. doi:10.1016/j.biocon.2010.01.013

Balasubramanian, R., Yadav, P. D., Sahina, S., Nadh, V. A. (2019) Distribution and prevalence of ticks on livestock population in endemic area of Kyasanur forest disease in Western Ghats of Kerala, South India. Journal of Parasitic Diseases, 43, 256-262. https://doi. org/10.1007/s12639-019-01086-7

Barrion, A. T., Litsinger, J. A. (1995) Riceland spiders of South and Southeast Asia. Cab International, Wallingford, England, 736.

Bucher, R., Menzel, F., Entling, M. H. (2015) Risk of spider predation alters food web structure and reduces local herbivory in the field. Oecologia, 178, 571-577. DOI 10.1007/s00442-015-3226-5

Caleb, J. T. D. (2016) Taxonomic notes on some ant-mimicking jumping spiders (Araneae: Salticidae) from India. Arthropoda Selecta, 25, 403-420.

Caudill, S. A., Vaast, P., Husband, T. P. (2014) Assessment of small mammal diversity in coffee agroforestry in the Western Ghats, India. Agroforestry Systems, 88, 173-186. DOI 10.1007/s10457-013-9664-3

Chakraborty, D., Reddy, M., Tiwari, S., Umapathy, G. (2019) Land Use Change Increases Wildlife Parasite Diversity in Anamalai Hills, Western Ghats, India.
Scientific reports, 9, 1-11. https://doi.org/10.1038/ s41598-019-48325-8

Cincotta, R. P., Wisnewski, J., Engelman, R. (2000) Human populations in the biodiversity hotspots. Nature, 404, 990-992.

Colebourn, P. H. (1974) The influence of habitat structure on the distribution of Araneus diadematus Clerck. The Journal of Animal Ecology, 43, 401-409. https:// www.jstor.org/stable/3372

De Fries, R., Karanth, K. K., Pareeth, S. (2010) Interactions between protected areas and their surroundings in human-dominated tropical landscapes. Biological conservation, 143, 2870-2880. https://doi. org/10.1016/j.biocon.2010.02.010

Dey, A., Debnath, S., Debbarma, B., Chaudhuri, P. S. (2013) A preliminary study on spider diversity from a house hold garden (artificial mixed plantation) in West Tripura, India. Journal of Research in biology, 3 , 1009-1017. http://jresearchbiology.com/documents/ RA0361.pdf.

Dhali, D. C., Jose, S. K., Sureshan, P. M. (2017) Arachnida: Araneae (Spiders). Freshwater faunal diversity in India. In:Kailashchandra, Gopi, K. C., Rao, D. V., Valarmathi, K. \& Alfred, J. R. B. (Eds.), Current Status of freshwater faunal diversity in India (pp. 333-343). Zoological Survey of India.

Dharmaraj, J., Gunasekaran, C., Rajkumar, V., Chinnaraj, P. (2017) Diversity of spiders (Arachnida: Araneae) in Nilgiris, Tamilnadu. International Journal of Advanced Research in Biological Sciences, 4, 143-147. http://dx.doi.org/10.22192/ijarbs.2017.04.05.015

Downie, I. S., Wilson, W. L., Abernethy, V. J., McCracken, D. I., Foster, G. N., Ribera, I., Waterhouse, A. (1999) The impact of different agricultural land-uses on epigeal spider diversity in Scotland. Journal of insect Conservation, 3, 273-286. https://doi. org/10.1023/A:1009649222102

Gravely, F. H. (1931) Some Indian spiders of the families Ctenidae, Sparassidae, Selenopidae and Clubionidae. Records of the Indian Museum, 33, 211-282.

Greenstone, M. H. (1984) Determinants of web spider species diversity: vegetation structural diversity vs. prey availability. Oecologia, 62, 299-304. http://www. jstor.com/stable/4217321

Greenstone, M. H. (1999) Spider predation: how and why we study it. Journal of Arachnology, 27, 333-342. https://www.jstor.org/stable/3706005

Helsdingen, P. J. (1969) A reclassification of the species of Linyphia Latreille based on the functioning of the genitalia (Araneida, Linyphiidae). Zoologische Verhandelingen, 105, 1-303. 
Henaut, Y., Pablo, J., IbarraNunez, G., Williams, T. (2001) Retention, capture and consumption of experimental prey by orb-web weaving spiders in coffee plantations of Southern Mexico. Entomologia Experimentalis et Applicata, 98, 1-8. https://doi.org/10.1046/j.15707458.2001.00750.x

Hill, M. O. (1973) Diversity and evenness: a unifying notation and its consequences. Ecology, 54, 427-432. https://doi.org/10.2307/1934352

Huber, B. A. (2000) New World pholcid spiders (Araneae: Pholcidae): A revision at generic level. Bulletin of the American Museum of Natural History, 254, 1-348.

Jose, A. C., Sudhin, P. P., Prasad, P. M., Sreejith, K. A. (2018) Spider Diversity in Kavvayi River Basin, Kerala, Southern India. Current World Environment, 13, 100-112. DOI:10.12944/CWE.13.1.10

Kapoor, V. (2008) Effects of rainforest fragmentation and shade-coffee plantations on spider communities in the Western Ghats, India. Journal of Insect Conservation, 12, 53-68. https://doi.org/10.1007/s10841-006-9062$\underline{5}$

Karthikeyani, R., Caleb, J. T. D., Gajbe, U. A., Muthuchelian, K. (2017) Checklist of spiders (Arachnida: Araneae) of the state of Tamil Nadu, India. Munis Entomology and Zoology Journal, 12, 180-193.

Kumar, A., Gopi, G., Prajeesh, P. (2010) Genetic erosion and degradation of ecosystem services in wetland rice fields: a case study from Western Ghats, India. In: Stewart, L., David, C. (Eds.), Agriculture, Biodiversity and Markets: Livelihoods and Agroecology in Comparative Perspective (pp. 137-156). Earthscan, London.

Kumar, S. A. V., Ichikawa, K. (2010) Homegardens: sustainable land use systems in Wayanad, Kerala, India. Sustainable use of biological di-versity in socio-ecological production landscapes, 52, 125.

Kumara, H. N., Singh, M. (2004) The influence of differing hunting practices on the relative abundance of mammals in two rainforest areas of the Western Ghats, India. Oryx, 38, 321-327. https://doi.org/10.1017/ S0030605304000560

Liu, S., Chen, J., Gan, W., Schaefer, D., Gan, J., Yang, X. (2015) Spider foraging strategy affects trophic cascades under natural and drought conditions. Scientific reports, 5, 12396. https://doi.org/10.1038/srep12396

Lone, M. A., Dar, I. Y., Bhat, G. A. (2015) A study on ecological distribution and community diversity of spiders in Gulmarg Wildlife Sanctuary of Kashmir Himalaya. Journal of Ecology and the Natural Environment, 7, 81-86. https://doi.org/10.5897/JENE2015.0500
Ludwig, L., Barbour, M. A., Guevara, J., Aviles, L., Gonzalez, A. L. (2018) Caught in the web: spider web architecture affects prey specialization and spider-prey stoichiometric relationships. Ecology and evolution, 8, 6449-6462. https://doi.org/10.1002/ece3.4028

Malvido Benitez, J., Martinez-Falcon, A. P., Duran-Barron, C. G. (2020) Diversity metrics of spider communities associated with an under storey plant in tropical rain forest fragments. Journal of Tropical Ecology, 36, 47-55. https://doi.org/10.1017/S026646741900035X

Mandle, L., Ticktin, T. (2015) Moderate land use changes plant functional composition without loss of functional diversity in India's Western Ghats. Ecological Applications, 25, 1711-1724. https://doi.org/10.1890/150068.1

Marc, P., Canard, A., Ysnel, F. (1999) Spiders (Araneae) useful for pest limitation and bioindication. Agriculture, Ecosystems and Environment, 74, 229-273. https://doi.org/10.1016/S0167-8809(99)00038-9

Michalko, R., Pekar, S., Dula, M., Entling, M. H. (2019) Global patterns in the biocontrol efficacy of spiders: A meta-analysis.Global Ecology and Biogeography, 28, 1366-1378. https://doi.org/10.1111/geb.12927

Nyffeler, M. (2000) Ecological impact of spider predation: a critical assessment of Bristowe's and Turnbull's estimates. Bulletin of the British arachnological Society, 11, 367-373.

Nyffeler, M., Benz, G. (1987) Spiders in natural pest control: A review 1. Journal of Applied Entomology, 103, 321-339. https://doi.org/10.1111/j.1439-0418.1987. tb00992.x

Prasad, A. K., Roy, S., Sen, S., Neave, S., Nagpal, A., Pandit, V. (2020) Impact of different pest management practices on natural enemy population in tea plantations of Assam special emphasis on spider fauna. International Journal of Tropical Insect Science, 8, 1-7. https://doi.org/10.1007/s42690-020-00111-0

Radermacher, N.,Hartke, T. R., Villareal, S., Scheu, S. (2020) Spiders in rice-paddy ecosystems shift from aquatic to terrestrial prey and use carbon pools of different origin. Oecologia, 192, 801-812. https://doi. org/10.1007/s00442-020-04601-3

Rahman, P. M., Varma, R. V., Sileshi, G. W. (2011) Abundance and diversity of soil invertebrates in annual crops, agroforestry and forest ecosystems in the Nilgiri biosphere reserve of Western Ghats, India. Agroforestry Systems, 85, 165-177. DOI 10.1007/s10457011-9386-3

Raju, B. M. K., Rao, K. V., Venkateswarlu, B., Rao, A. V. M. S., Rao, C. R., Rao, et al. (2013) Revisiting climatic classification in India: a district-level analysis. 
Current Science, 105, 492-495. https://www.jstor.org/ stable/24098002

Ranganathan, J., Krishnaswamy, J., Anand, M. O. (2010) Landscape-level effects on avifauna within tropical agriculture in the Western Ghats: Insights for management and conservation. Biological Conservation, 143, 2909-2917. https://doi.org/10.1016/j.biocon.2010.04.018

Rendon, M. A. P., Ibarra-Nunez, G., Parra-Tabla, V., Garcia-Ballinas, J. A., Henaut, Y. (2006) Spider diversity in coffee plantations with different management in Southeast Mexico. Journal of Arachnology, 34, 104112. https://www.jstor.org/stable/4489047

Riechert, S. E. (1999) The hows and whys of successful pest suppression by spiders: insights from case studies. Journal of Arachnology, 27, 387-396. http:// www.jstor.com/stable/3706011

Riechert, S. E., Bishop, L. (1990) Prey control by an assemblage of generalist predators: spiders in garden test systems. Ecology, 71, 1441-1450. https://doi. org $/ 10.2307 / 1938281$

Riechert, S. E., Gillespie, R. G. (1986) Habitat choice and utilization in web-building spiders. In: Shear, W. A. (Eds.), Spiders: Webs, Behavior and Evolution (pp. 23-48.). Stanford University Press.

Rodriguez, J., Waichert, C., Von Dohlen, C. D., Poinar, G., Pitts, J. P. (2015) Eocene and not Cretaceous origin of spider wasps: Fossil evidence from amber. Acta Palaeontologica Polonica, 61, 89-96. https://doi. org/10.4202/app.00073.2014

Rosenzweig, M. L. (1995) Species diversity in space and time (Vol.1).Cambridge University Press. UK. https:// doi.org/10.1017/CBO9780511623387

Rossi, J. P., Blanchart, E. (2005) Seasonal and land-use induced variations of soil macrofauna composition in the Western Ghats, southern India. Soil biology and biochemistry, 37, 1093-1104. https://doi. org/10.1016/j.soilbio.2004.11.008

Rypstra, A. L., Carter, P. E. (1995) The web-spider community of soybean agro ecosystems in south western Ohio. Journal of Arachnology, 23, 135-144. http:// www.jstor.com/stable/3705463

Samiayyan, K. (2014) Spiders-The generalist super predators in agro-ecosystems. In: Abrol, D. P. (Eds.), Integrated Pest Management (pp. 283-310). Academic Press. https://doi.org/10.1016/B978-0-12398529-3.00016-6

Sanders, D., Platner, C. (2007) Intraguild interactions between spiders and ants and top-down control in a grassland food web. Oecologia, 50, 611-624. DOI 10.1007/s00442-006-0538-5
Sankaran, P. M., Sebastian, P. A., (2018) A taxonomic misidentification of the orb-weaving spider Acusilas coccineus Simon, 1895 ((Araneae, Araneidae). Zootaxa, 4434, 391-395.

Sebastian, P. A., Sudhikumar, A. V., Mathew, M. J., Sunish, E. (2012) Diversity of spiders (Araneae) in the Western Ghats-an overview. In:Priyadarsanan, D. R., Soubadra, D., Aravind, M., Subramanian, K. A., Seena N. (Eds.), Invertebrate diversity and conservation in the Western Ghats (pp. 235-247). ATREE, Bangalore.

Sruthi, R., Smija M. K., Thressiamma, V. T., Prasadan P. K. (2019) Spider diversity (Arachnida: araneae) in different ecosystems of the Western Ghats, Wayanad region, India. South Asian Journal of Life Sciences, 7, 29-39. http://dx.doi.org/10.17582/journal.sajls/2019/7.2.29.39

Stokmane, M., Spungis, V. (2016) The influence of vegetation structure on spider species richness, diversity and community organization in the Apsuciems calcareous fen, Latvia. Animal Biodiversity and Conservation, 39, 221-236. https://doi.org/10.32800/ abc.2016.39.0221

Sudhikumar, A. V., Mathew, M. J., Sunish, E., Murugesan, S., Sebastian, P. A. (2005) Preliminary studies on the spider fauna in Mannavan shola forest, Kerala, India (Araneae). European Arachnology Supplement, 1, 319-327.

Sunderland, K. (1999) Mechanisms underlying the effects of spiders on pest populations.Journal of Arachnology, 27, 308-316. http://www.jstor.com/stable/3706002

Sunderland, K., Samu, F. (2000) Effects of agricultural diversification on the abundance, distribution, and pest control potential of spiders: a review. Entomologia Experimentalis et Applicata, 95, 1-13. https://doi. org/10.1046/j.1570-7458.2000.00635.x

Tikader, B. K. (1982) Family Araneidae (Argiopidae). Typical orb-weavers. Zoological Survey of India, Calcutta, 2, 1-293.

Tikader, B. K., Biswas, B. (1981) Spider fauna of Calcutta and vicinity. Records of the Zoological Survey of India, Occasional Paper, 30, 1-149.

Tikader, B. K., Malhotra, M. S. (1980) Fauna of India, spiders (Lycosidae).Zoological Survey of India, Calcutta, 2, 248-447.

Uetz, G. W. (1979) The influence of variation in litter habitats on spider communities. Oecologia, 40, 29-42. https://doi.org/10.1007/BF00388808

Uetz, G. W. (1991) Habitat structure and spider foraging. In: Bell S. S., McCoy E. D., Mushinsky, H. R. (Eds.), Habitat Structure. Population and Community Biolo- 
Fathima P Shabnam et al. - Spider Diversity in Different Plantations of Western Ghats, India

gy Series (pp. 325-348). Springer, Dordrecht.https:// doi.org/10.1007/978-94-011-3076-9 16

Wise, D. H. (1993) Spiders in ecological webs. Cambridge University Press, New York, 291-315. https://doi. org/10.1017/CBO9780511623431

Żabka, M. (1985) Systematic and zoogeographic study on the family Salticidae (Araneae) from Vietnam. Annales Zoologici, 39, 197-485. 